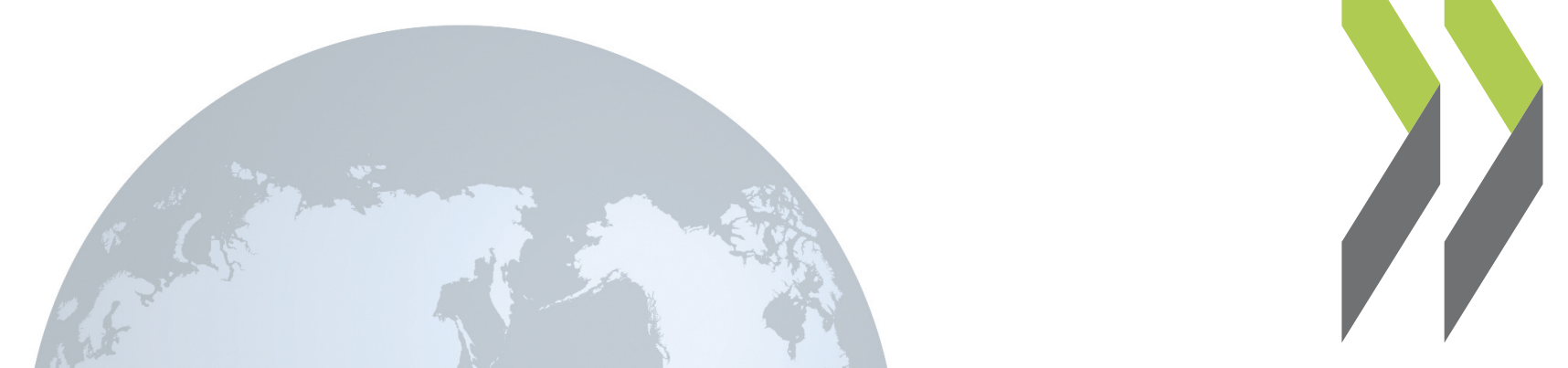

OECD Labour Market and Social Policy Occasional Papers No. 4

\title{
Statistics of Annual Earnings in OECD Countries
} David Grubb 


\title{
LABOUR MARKET AND SOCIAL POLICY OCCASIONAL PAPERS
}

\author{
No. 4 \\ STATISTICS OF ANNUAL EARNINGS \\ IN OECD COUNTRIES \\ by
}

David Grubb 



\title{
DIRECTORATE FOR SOCIAL AFFAIRS, MANPOWER AND EDUCATION
}

\author{
OCCASIONAL PAPERS
}

\begin{abstract}
This series is designed to make available to a wider readership selected labour market and social policy studies prepared for use within the OECD. Authorship is usually collective, but principal writers are named. The papers are generally available only in their original language - English or French - - with a summary in the other.

Comment on the series is welcome, and should be sent to the Directorate for Social Affairs, Manpower and Education, 2, rue André-Pascal, 75775 PARIS CEDEX 16, France. Additional, limited copies are available on request.
\end{abstract}

The opinions expressed and arguments employed here are the responsibility of the author(s) and do not necessarily represent those of the OECD. 


\section{LABOUR MARKET AND SOCIAL POLICY OCCASIONAL PAPERS}

(Already available, free of charge)

No. 1 AN ECONOMIC FRAMEWORK FOR THE EVALUATION OF CHILD CARE POLICY (1990) (Donald Verry)

No. 1 UN CADRE ÉCONOMIQUE POUR L'ÉVALUATION DES POLITIQUES DE GARDE D'ENFANT (1990) (Donald Verry)

NO. 2 HEALTH AND PENSION REFORM IN JAPAN (1990)

No. 3 WRONGFUL TERMINATION LITIGATION IN THE UNITED STATES AND ITS EFFECT ON THE EMPLOYMENT RELATIONSHIP (1990) (Susan R. Mendelsohn)

\section{Mailing List for \\ Labour Market and Social Policy Occasional Papers}

Please include the following name on the mailing list:

(write in capitals)

Name

Organisation

Address

Country

This form should be returned to:

Labour Market and Social Policy Occasional Papers

Directorate for Social Affairs, Manpower and Education

OECD

2, rue André-Pascal

75775 PARIS CEDEX 16

FRANCE 


\section{A SELECTION OF OECD PUBLICATIONS ALSO AVAILABLE}

\section{"OECD SOCIAI ROLICY STUDIES" SERIES}

NO. 1 SOCIAI EXPENDITURE 1960-1990: Problems of Growth and Control (1985)

Out of print in English. French text available under the title:

No. I Dépenses sociales 1960-1990. Problèmes de croissance et de mâttrise.

(81 8501 2) ISBN 92-64-22656-7, 100 pp.

$£ 7.50$ US\$15.00 FF75 DM33

NO. 2 MGASURING HWALTH CARE 1960-1983: Expenditure, Costs and Performance (1985) (81 85061$)$ ISBN 92-64-12736-4, $162 \mathrm{pp}$.

Out of print. Available on microfiche edition.

$\begin{array}{lllll}\text { Price per microfiche: } & £ 2.50 & \text { US\$4.50 } & \text { FF20 DM8 }\end{array}$

No. 3 IIVING CONDITIONS IN OECD COUNTRIJS: A Compendiun of Social Indicators

(1986) (81 8504 1)ISBN $92-64-12734-8,166$ pp. $£ 6.50 \quad$ US\$13.00 FF65 DM29

NC. 4INAWCING AND DELIVIRING HWALTH CARE: A COMparative AnaIysis Of OECD Countries (1987)

( 8187021 ) ISBN $92-64-12973-1,102$ pp.

$£ 11.00$ US\$19.00 FF90 DM37

NO. 5 RETORMING PUBLIC PENSIONS (1988)

( 8188041 ) ISBN $92-64-13123-X, 250$ pp.

$£ 15.50$ US\$29.00 FF130 DM56

NO. 6 THE FUTURE OF SOCIAT PROTECTION (1988)

( $818803 \quad 1$ ) ISBN $92-64-13152-3,64 \mathrm{pp}$.

$£ 8.50$ US\$15.50 FF70 DM31

NO. 7 HEALTE CARE SYSTEMS IN TRANSITION: The Search for Efficiency (1990)

(81 8905 1) ISBN $92-64-13310-0,206 \mathrm{pp} . \quad £ 17.00 \quad$ US\$30.00 FF140 DM55

Ho. 8 IONE PARENT FAMILIES: The Economic Challenge (1990)

$\left(\begin{array}{lllll}81 & 89 & 04 & 1\end{array}\right)$ ISBN $92-64-13303-8,252$ pp. $\quad £ 20.00$ US\$34.00 FF160 DM66

\section{EMPLOYMENT}

OECD EMPLOMENT OUTLOOK July 1990 (published annually)

(819002 1) ISBN $92-64-13396-8,212 \mathrm{pp}$. £23.00

US\$40.00 FF190 DM78

THE INTEGRATION OF WOMEN INTO THE ECONOMY (1985)

(81 8505 1) ISBN $92-64-12735-6,184 \mathrm{pp} . \quad £ 10.00 \quad$ US\$20.00 FF100 DM44

MASURES TO ASSIST THE LONG-TERM UNEMPLOYED -- Recent Experience in SOMe OECD Countries (1988)

(81 8806 1) ISBN $92-64-13134-5,100$ pp. $\quad \& 7.50 \quad$ US\$13.50 FF60 DM26

ILABOUR MARKET FLEXIBILITY: Trends in Enterprises (1989)

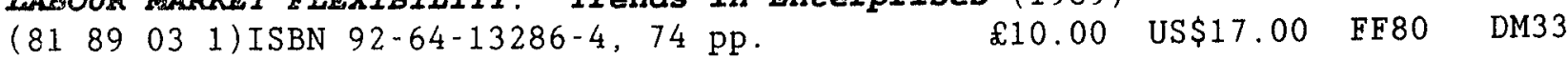


MECHANISMS TOR JOB CRHATION: Lessons from the United states (1989)

(81 8801 1) ISBN $92-64-13186-8,228 \mathrm{pp}$.

$£ 14.50$ US\$25.50 FF120 DM50

NEW TECENOLOGY IN THW 1990S: A SOCio-zconomic StrategY (1989)

(81 8807 1) ISBN 92-64-13180-9, $130 \mathrm{pp}$.

$£ 11.00$ US\$19.00 FF90 DM37

IABOUR MARKET POLICIES FOR THE 1990S (1990)

(81 90011 ) ISBN $92-64-13363-1,130 \mathrm{pp}$.

$£ 13.00$ US $\$ 23.00 \quad$ FF110 DM43

\section{DEMOGRAPHY}

AGEING POPULATIONS: The Social Policy Implications (1988)

(81:88 02 1) ISBN $92-64-13113-2,90 \mathrm{pp}$.

$£ 12.00$ US\$22.00 FF100 DM43

\section{CHILD CARE}

CHIIDREN AND SOCIETY: Issues for Pre-school Reforms (1981)

(96 81012 ) ISBN $92-64-22210-3,249 \mathrm{pp}$.

$£ 7.60 \quad$ US\$17.00 FF76 DM38

(out of print)

CARING FOR YOUNG CHILDRHN (1982)

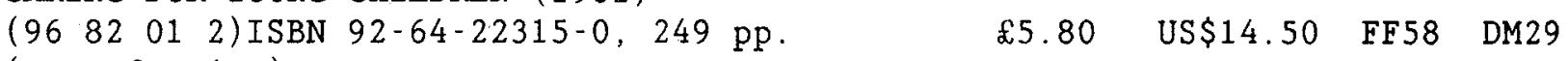
(out of print)

"CHILD CARE IN OECD COUNTRIES", in OrCD Employment out1ook, July 1990, chapter 5 .

Prices charged at the OECD Bookshop THE OECD CATALOGUE OF PUBLICATIONS and supplements will be sent free of charge on request addressed either to OECD Publications Service, 2, rue André-Pascal, 75775 PARIS CEDEX 16 or to the OECD Distributor in your country 
Existing multi-country earnings statistics generally relate to only a fraction of the economy's industries and occupations, often to manual workers in manufacturing industry. This paper discusses the annual basis of measurement, which has particular advantages when aggregations or comparisons of earnings need to be made across sectors, occupations, or countries that have markedly differing payment systems. Three main types of statistic of annual earnings are identified: estimates of annual earnings of the Average Production Worker (in manufacturing only), made in connection with OECD calculations of tax rates; aggregate wages and salaries per employee, corrected onto a full-time equivalent basis; and statistics based on individual data, which may come from household surveys, employer surveys or tax and social security records. Some comparisons among the available statistics examine to what extent the differing indicators give similar impressions as regards the level and trend of earnings.

An earlier version of this paper was submitted for discussion to the OECD's Working Party on Employment and Unemployment Statistics and Working Party on Employment. Particular thanks are due to several countries which have supplied publications and other information from their surveys of income or earnings directly to the Secretariat for the paper.

Les statistiques de gains multi-pays ne couvrent généralement qu'une partie des branches d'activité et des professions, le plus souvent ceux des ouvriers des industries manufacturières. Ce texte étudie la mesure sur une base annuelle qui présente certains avantages lorsqu'on veut procéder à des agrégats ou à des comparaisons de gains entre secteurs, professions ou pays dont les systèmes de rémunération sont très différents. On y distingue trois types de données sur les gains annuels : les estimations des gains annuels de 1'ouvrier moyen (dans le secteur manufacturier) qui sont établies par 1'OCDE conjointement avec les calculs des taux d'imposition; les traitements et salaires globaux par salarié convertis en équivalent salarié à plein temps; et les statistiques sur les personnes privées, qui peuvent provenir soit d'enquêtes auprès des ménages et des employeurs, soit des registres des impôts ou de la sécurité sociale. Des comparaisons entre les statistiques disponibles montrent à quel point les différents indicateurs permettent des interprétations similaires en ce qui concerne le niveau et l'évolution des gains.

Une version préliminaire de ce document a été présentée au Groupe de travail sur les statistiques de l'emploi et du chômage et au Groupe de travail sur l'emploi. L'auteur tient à remercier les autorités nationales qui ont transmis au Secrétariat les publications et les informations provenant de leurs enquêtes sur les revenus ou les gains. 
TABLE OF CONTENTS

A. INTRODUCTION

Paras

B. SOME COMMON LIMITATIONS OF EARNINGS STATISTICS

$1-3$

B.1. Population covered

B.2. Coverage of unusual types of earned income

$4-5$

$6-11$

12

B.3. Direct reporting

$13-16$

B.4. Accuracy of reported earnings in household surveys

$17-18$

B.5. Links with national accounts and with employment statistics

B.6. Limitations of earnings statistics, summary

C. SOURCES OF AVERAGE ANNUAL EARNINGS STATISTICS

C.1. Earnings statistics from existing multi-country sources $23-30$

C.2. Earnings per full-time equivalent employee

$31-33$

C.3. Statistics from data on the annual earnings of individuals

$34-37$

D. COMPARISONS OF THREE ESTIMATES OF ANNUAL AVERAGE EARNINGS

$38-43$

E. SUMMARY AND CONCLUSION

$44-48$

NOTES

REFERENCES

Pages

TABLES

ANNEX A. Currency units used in tables

ANNEX B. Concepts and definitions in annual statistics of

ANNEX C. Definition and sources for information on full-year full-time earnings

\section{LIST OF TABLES}

1. Wages and salaries per employee

2. Earnings of the Average Production Worker

3. National estimates of employee earnings per full-time equivalent employee

4. The share of part-time employment in total employment

6. Average annuel earnings of full-year full-time workers by sex Coverage of survey statistics of earnings reported in Table 5

8. Comparisons of earnings estimates for the full-year full-time worker and for wages and salaries per full-time equivalent employee

9. Comparisons of earnings estimates for the full-year full-time worker and for the Average Production Worker

10. Ratio between the earnings estimates for wages and salaries per full-time equivalent employee and for the Average Production Worker 


\section{STATISTICS OF ANNUAL EARNINGS IN OECD COUNTRIES}

\section{A. INTRODUCTION}

1. Multinational statistics for earnings, available in publications from the ILO and the OECD, generally cover only a fraction of employment. The definitional bases used vary greatly, and do not allow comparisons of the general level of earnings across countries. To the extent that comparisons of earnings across industries, occupations, by sex, etc, within countries can be made in such statistics, they are liable to be misleading. For example, male and female earnings can generally only be compared for production workers, and then often only in manufacturing: yet production work in manufacturing is a declining minority of all employment and is now a particularly small fraction of women's employment (1).

2. This note examines statistics of average annual earnings. On an annual basis of measurement, statistics covering all or nearly all occupations and industries in the economy are more widely available. Statistics on this basis may be used directly for making comparisons of the level of earnings or trends in earnings across countries, or indirectly as a basis for assessing the microeconomic impact of policy measures (that is, tax thresholds, social security contribution ceilings, minimum wage rates, etc., may be compared across countries or through time by expressing them as a proportion of national average earnings). When such statistics are drawn from surveys, they can provide a valid basis for comparisons of earnings across groups within the economy, owing to their wide coverage. The aim of this note therefore is to inform readers of the characteristics and availability of annual earnings statistics, to facilitate access to those statistics that can be derived in multi-national form from existing publications, and to present further information from a variety of national sources.

3. Section B discusses in general terms some of the considerations that affect the accuracy and conceptual appropriateness of earnings statistics. Section $C$ describes three different types of estimates of full-time annual earnings. First is the concept of earnings of the "Average Production Worker", already in use in multi-country analysis. Second, it is possible to estimate wages and salaries per full-time equivalent employee. There are some national official estimates on this basis, and estimates can be made on a multi-country basis using statistics for the share of part-time work in total employment. Third, statistics can be drawn from national sources that directly record the annual earnings of individuals and their work status over the year. A statistic frequently published from such surveys is the average earnings of full-year full-time employees. Section $D$ compares at the aggregate level the three main types of estimate discussed in Section C. Section E concludes. 


\section{B. SOME COMMON LIMITATIONS OF EARNINGS STATISTICS}

4. Theoretical models of labour supply usually consider the situation of individuals who are free to choose their hours of work, and thus consider that hourly earnings are the appropriate basis for analysis. For some applications (such as the comparison of tax schedules) the annual earnings basis is needed. However, it is important when using earnings statistics to consider some other constraints which influence how far the statistics capture a meaningful and appropriate concept. These constraints, as they frequently figure in existing earnings statistics, are the main topic of this section.

5. In general, factors which make for a conceptually satisfactory comparison of earnings by sex, age, occupation or industry within a country also make for a conceptually satisfactory comparison of earnings across countries, and vice versa. As far as possible, earnings statistics should cover a representative and clearly identified sample of the whole working population, should cover all earnings whether paid regularly or irregularly, should be drawn directly from easy-to-understand survey questions (or administrative sources) that refer to a clearly-defined concept of earnings and to a precise reference period, and should be accurate.

\section{Population covered}

6. Coverage of self-employment. Coverage of the self-employed, whose earnings are in many cases computed only once a year (for accounting and tax purposes) is generally only possible on an annual basis. However even annual earnings statistics often do not in practice cover the self-employed, and in the rest of this paper the term "earnings" will be used as shorthand when discussing statistics that relate only to employees and their wages and salaries.

7. Coverage according to methods of payment. Statistics of hourly earnings are often restricted to workers who are paid hourly: that is to say, mainly manual workers. Extensions of hourly earnings statistics to cover non-manual employees, whose actual hours of work are not generally recorded by their employers, are limited by the method used to estimate hours worked for non-manual employees. One possibility is to cover non-manuals on the basis of the weekly or monthly hours that are stipulated in their employment contract: however some non-manuals, perhaps high-paid (such as university teachers) will still not be covered on this basis, because their work contract specifies duties but not hours of work. Another possibility is to measure hours of work by asking the employee or his employer to estimate these, but such estimates may be hard to obtain and/or inaccurate. Clearly, this constraint applies only to estimates of hourly earnings. Statistics of weekly, monthly or annual earnings can cover without difficulty non-manual employees whose pay conditions contain no reference to hours of work. 
8. Coverage according to work intensity. Earnings statistics often cover only employees who have in some sense a full work record. This restriction itself can take two forms. Statistics may exclude those who have not been employed for the whole week, month, or year of the survey, or may in addition exclude any employees who, while remaining employed, have lost some pay during the survey period due to absences from work. As regards the restriction of statistics to individuals employed over the whole period surveyed, this restriction excludes relatively few people in hourly, weekly or even monthly earnings statistics, but rather large numbers of people in annual earnings statistics. As regards the restriction that excludes from the statistics individuals who have had pay docked due to short absences from work (such as late arrival in the morning), this essentially affects reported earnings for manual workers. This is because employers often keep records of such absences (and deduct pay accordingly) for hourly-paid manual employees, but not for weekly or monthly-paid non-manual employees.

9. Some indication of the importance of this issue in annual earnings statistics is given by a french survey that gave it close attention. Vlassenko (1981) found that 60 per cent of manuals in industry lost some pay due to absence from work during calendar 1978, and that the average annual pay of these workers was about 15 per cent lower than that of workers paid fully for the whole year. (This earnings difference could reflect not only hours worked but also differences in other worker/job characteristics). Thus, average earnings across all manuals continuously employed during the year were about 9 per cent lower than average earnings for the subset of these who spent the whole year without any recorded absence from work. Statistics from the New Earnings Survey (Great Britain) for $1978 / 79$ applied the less strict criterion of excluding from the sample of full-year employed those who had lost at least one week's pay due to absences from work. This criterion excluded 26 per cent of full-year employed male manuals and 7.5 per of full-year employed male non-manuals, and increased average earnings by 3.0 per cent and 1.2 per cent respectively.

10. Some implications relevant to annual earnings statistics are:

- a more restrictive concept of "full-year" work (leading to lower coverage) may lead to a higher recorded level of earnings;

- an estimate of average annual earnings, based on statistics of average weekly or monthly earnings for workers whose pay was unaffected by absence, will somewhat exceed actual annual average earnings;

- exclusion of workers whose pay was affected by absence from the pay statistics may overstate the true earnings situation of hourly paid workers (those who clock in to work) as compared with non-manual workers whose presence at work is less tightly controlled.

Apart from the question of consistency across groups within the survey, from the point of view of consistency with national accounts and labour force statistics it seems preferable to base measures of annual earnings upon the record of employment over the year, on the normal labour force definitional basis. This is usual practice in household-based surveys. 
11. Coverage of irregular forms of employment. Statistics of hourly, weekly or monthly earnings are relatively often obtained through employer surveys, while statistics of annual earnings are relatively often obtained from tax or social security records, or a household survey. Employer surveys usually cover only employees with a regular employment contract, while household surveys and in some countries tax and social security records are more likely to include temporary employees and day labourers. The coverage of irregular forms of employment is particularly important in some countries if the surveys are to be used to assess the frequency of low earnings in the economy.

\section{Coverage of unusual types of earned income}

12. Another issue, distinct from the question of population covered, is that of the types of income recorded for employees in the covered population. Statistics of hourly, weekly or monthly earnings often report regular hourly, weekly or monthly pay, which does not include the 13 th or 14 th month payments and annual bonuses that are important components of employee earnings in Japan and many European countries, or the irregular bonuses that tend to be important in particular occupations such as sales. Surveys of annual earnings usually record wages and salaries on a basis similar to that used for taxation purposes, which generally includes all the more common forms of money payment, though some remuneration (e.g. executive remuneration in the form of stock options) may still be omitted.

\section{Direct reporting}

13. Hourly, weekly and monthly earnings can only be directly reported for restricted populations: for example hourly earnings can only be reported direct3y for workers who are paid on an hourly basis. When statistics have more comprehensive coverage, and notably when they cover non-manuals as well as manuals, they will in most countries refer to some workers who are paid monthly and others who are paid weekly or by other periods, such as every two weeks.

14. Because pay periods differ across workers, employer-based surveys often record earnings in the "usual" pay period and the length of that pay period. Reported statistics are then based upon a calculation, converting all the periods reported to the same basis. Thus an earnings statistic with a reasonably wide coverage, nominally on the basis of weekly or monthly earnings, will in fact reflect a mixture of earnings periods and relate to no single time period or date. This is not solely an issue of accounting units: for example, more workers are absent from work once during a period of a month, than during a period of a week, so that statistics of earnings for workers whose pay was not affected by absence will be influenced by the "usual" pay period, which varies by enterprise and occupation within the enterprise.

15. Household surveys can invite respondents to report their usual pay period and the pay actually or usually received over that period: but regular surveys more often circumvent the problem of the payment period completely, by simply asking repondents to report their weekly or monthly earnings (perhaps on a "usual" basis). This leaves the respondent to convert the payment frequency and to decide whether the question is a reference to past or expected future 
earnings, how to allow for overtime payments or time absent from work, whether to include bonuses, etc.: so the resulting statistics have no precise definition.

16. Annual earnings statistics from surveys or tax sources are conceptually relatively simple, being reports of total earnings received for a given year.

\section{Accuracy of reported earnings in household surveys}

17. Statistics of earnings may come from representative samples of tax or social security records, employer surveys, or household surveys. Of these, only the household survey can give detailed complementary information about the earner: his or her family circumstances, age, education, etc. In Sweden and Finland, and to some extent in some other countries such as Australia, some household surveys are combined with data from tax records in order to help ensure that incomes and earnings are accurately recorded. However, in most countries the earnings (or incomes) recorded in household surveys are self-reported, and their accuracy is an important issue.

18. Self-reporting of weekly or monthly earnings is intrinsically difficult. Many hourly paid workers' earnings fluctuate from week to week, and the last received pay may be recalled on a net rather than pre-tax basis, and may relate to earlier work in a somewhat complicated fashion (e.g. a week's pay may be the sum of basic pay for the most recent week with overtime payments for the week before). Questions that would allow calculation of earnings on a standard weekly or monthly basis and determine the level of employment over the reported earnings period would be complicated, and are not often used. A question relating to total earnings over the last tax year is simpler and less liable to misinterpretations. Perhaps because of such factors, a United States study which directly checked the accuracy of self-reported earnings against the employer's records of how much had been paid concluded that annual earnings were much more accurately reported than weekly earnings (2).

\section{Links with national accounts and employment statistics}

19. Sources of statistics for annual earnings (tax, social security, household and in some cases employer surveys), because they more often aim to record earnings of all types of employees and for all forms of payment, lend themselves more easily to integration with or cross-checking against national accounts and total employment data than do surveys over shorter periods. This link is discussed further in Annex B.

\section{Limitations of earnings statistics, summary}

20. This brief survey has not studied the defects of specific surveys, but rather features of the real world which affect all surveys, and make it difficult to produce statistics that are satisfactory from all points of view (coverage, accuracy, etc.). Statistics of earnings on an annual basis have some significant advantages over more widely-used statistics on an hourly, weekly or monthly basis. This is particularly true in a multi-country context, because the definition and coverage of statistics of hourly, weekly and monthly 
earnings is a function of institutional structures which vary greatly from country to country (such as the frequency of payment by the hour, week or month, and the proportion of workers whose pay is subject to control for absences from work). These advantages of the annual earnings basis for cross-country comparisons, and the fact that there is considerable scope for improving the availability of this particular type of statistic, motivate the concentration on the annual statistics in this note.

21. Given this concentration on annual statistics, some of their typical limitations should be kept in mind. Statistics from direct surveys of annual earnings commonly cover only workers employed for the whole year. This leaves the earnings position of workers with unstable employment records under-represented, and distorts the reported earnings levels in industries and occupations that have stable employment, as compared with those typically having high job turnover. Technically it would often be possible to include part-year workers in annual earnings statistics, including their earnings at an annual rate on the basis of the fraction of the year they worked. This is not very often done, perhaps because it introduces conceptual complications or because it increases reliance upon the data for weeks or months worked by workers employed only part of the year, which may be inaccurate.

22. Another area where the annual period has conceptual disadvantages is that an individual's industry, part-time/full-time, etc., status is more likely to change over a year than over a shorter period. Classifications by industry, marital status etc. may typically be on the basis of the status held longest over the year. This is clearly less precise than status during a past week.

\section{SOURCES OF AVERAGE ANNUAL EARNINGS STATISTICS}

\section{Earnings statistics from existing multi-country sources}

23. This section does not attempt to cover all national sources: it is limited to considering earnings statistics currently available on a multi-country basis.

24. Statistics on a non-annual basis. The ILO Yearbook of Labour Statistics gives statistics so far as possible for all sectors of the economy, but in principle relating only to production workers. Differences across countries in what is actually tabulated (hourly rates, hourly earnings, weekly and monthly earnings, sometimes for production and sometimes for all workers, etc, for varying sectors of the economy, etc) limit the international comparisons that can be made, especially outside manufacturing. OECD Main Economic Indicators contains a variety of statistics of earnings for use as short-term indicators: historical series in a relatively standardized presentation (in the form of year-to-year changes) are reported in Main Economic Indicators Historical Statistics 1960-1986, Table 9.1, "Hourly earnings in manufacturing". However, in practice 8 of the 21 series here relate to another time period, or to wage rates rather than earnings, or to a different industry coverage. 
25. Compensation and/or wages and salaries per employee. In the OECD's Economic Outlook and in the forecasts it reports (also in the 1989 Employment Qutlook, Table 1.8), labour costs are measured on the basis of compensation of employee per employee in the business sector, or in the whole economy if business sector statistics are unavailable. In general, this basis is used only for reporting year-to-year changes. However levels of compensation per employee for the whole economy can be computed on an approximately comparable basis using statistics in OECD National Accounts and OECD Labour Force Statistics (3).

26. The concept of compensation per employee is a measure of the cost of labour to employers. This differs from the wages and salaries received by employees by including employers' compulsory social security contributions and voluntary pension, etc., contributions. For many countries, wages and salaries per employee can be also be calculated. That is, the total wage and salary bill for the whole economy and the whole year is divided by total dependent employment. In most countries, but not all, the employment statistics are on an annual average basis (average of quarterly or monthly estimates). This gives results shown in Table 1.

27. Part-year employees appear only fractionally in statistics for the annual average level of employment. Thus wages and salaries per employee, as in Table 1, are a measure of earnings on a equivalent full-year basis (the significance of this is considered further in Annex B). However, the statistics are not in any sense on a full-time basis: they are averages across all weekly hours of work from 1 hour per week upwards. While comparisons of earnings by industry sector, and sometimes by sex, can be made on this basis, such figures may be misleading or of limited interest due to the large sex and sector variations in rates of part-time working (4). A correction for the incidence of part-time working may be possible on the basis of estimates of total hours of employee work by industry, but such estimates are available only for a few countries (5).

28. Earnings as estimated by combining information on the aggregate wage and salary bill with independent estimates of employee employment (or full-time equivalent employment) are subject to error due to differences in the coverage of the variables. This problem mainly concerns working owners of incorporated companies. Reflecting taxation practice, their earnings will appear as wages and salaries in the national accounts (the OECD National Accounts seem clear on this point). However, labour force surveys do not always determine for the own-account worker whether his business is incorporated, and labour statisticians" terminology (e.g. use of the term "dependent employment") tends to favour the interpretation that sole proprietors are to be considered as self-employed. Thus, a common situation in Table 1 and later derived Tables is probably that employee employment statistics exclude many sole proprietors of incorporated companies while the wage and salary totals include them. Comprehensive tax-based earnings statistics show that a substantial share of the total wage and salary bill can be involved (e.g. see Australian data in Annex B, Table B.3). 
29. The Average Production Worker's earnings. In the absence of any other appropriate statistics, the OECD Secretariat, with the co-operation of national authorities through their delegates to Working Party no. 2 of the Committee on Fiscal Affairs, has for some years estimated annual earnings of the "Average Production Worker" not for the benefit of general statistical users, but specifically as a basis for making computations of tax and benefit rates on a standardized basis. The Average Production Worker is defined as an adult worker directly engaged in production activity (manual or minor shop-floor supervisory work) in manufacturing industry, employed full-year (with no sickness or unemployment) and in a full-time job. The estimates should refer to the whole country and to both sexes and include regular cash supplements such as 13th month payments but not fringe benefits. Sources and methods of estimation are varied, with most of the estimates being calculations based upon published statistics relating to hourly, weekly or monthly earnings, with various adjustments.

30. The Average Production Worker statistics do not have the comprehensive coverage of other annual earnings statistics. However, with the exception of a few significant departures from the standard definition (notably, the estimates include all non-managerial manufacturing employees in Australia and all non-manual manufacturing employees in New Zealand, and in Belgium cover men only) these are the most widely available statistics on a full-time basis with a standard definition. Historical series are given in Table 2.

\section{Earnings per full-time equivalent employee}

31. The full-time equivalent basis for employment measurement takes one type of work as representing a single standard unit, and expresses other types of work as fractions of the standard unit depending upon their relative hours of work. A measure of annual earnings can be constructed by dividing the total wage and salary bill by full-time employees. Some country statistical services have themselves made estimates of annual earnings on this basis: at the time of writing, the Secretariat has obtained such series for Italy, New Zealand, and Norway, and these national estimates are given in Table 3 .

32. The standard units of employment used in Table 3 vary across countries. In the case of Italy, employment in a single regular job is the standard labour unit: employment in a non-regular job is given a weight less than 1, and employees with second jobs may have a total weight greater than 1 . Regular part-time work is not clearly identified in the underlying statistics, and the net result is that the total number of labour units slightly exceeds total employment. For New Zealand, statistics are estimates based upon an employer survey, and the standard unit is a single full-time job. In Norway, estimates refer to person-years of work and are substantially lower than total employment.

33. Time-series estimates of employment broken down into full-time and part-time were presented in the Employment Outlook 1989, Chart 1.2. The underlying statistics, which relate to the proportion of employment that is part-time, have not until now been published. They are given in Table 4. They are not closely comparable across countries: part-time status may be assessed in terms of self-perception or a threshold number of hours normally worked or of hours actually worked, statistics in some cases relate to employees only but 
more often to total employment, and in the latter case part-time employment may or may not include unpaid family workers working less than 10 or 15 hours per week. Despite these problems, the statistics probably do capture a large proportion of the variability in the frequency of part-time work for employees. In later sections of this paper they are used to convert the earnings estimates in Table 1 onto an approximate full-time equivalent basis, on the assumption that a part-time worker represents half a full-time equivalent. This calculation of full-time equivalency takes no account of second jobs, so that in this case the full-time worker, including his average hours of work in second jobs, is taken as representing a single standard equivalent unit.

\section{Statistics from data on the annual earnings of individuals}

34. Estimates of earnings which use national accounts statistics for the total wage and salary bill have little potential for analysis of earnings structure within countries, because analyses of aggregate wages and salaries are not generally available other than by industry. Study of the structure of annual earnings by sex, age, occupation, job tenure, enterprise size, etc. needs to be based upon surveys that record earnings for a representative sample of employees. A number of OECD countries have households surveys, employer surveys, or procedures for sampling tax records, which report the earnings of full-time workers on an annual basis. Earnings as reported from these sources are shown for 10 countries in Table 5, and detailed information about the sources is given in Annex C. The breakdown by sex is available in every country and is shown in Table 6 .

35. Where it was possible to choose, the earnings concept measured here was total annual wage and salary earnings of employees employed the whole year, mainly in a full-time job. The definitions actually used vary from this in France and Japan, where statistics include part-year workers with their earnings at an annual rate, and in the United Kingdom where workers who changed job during the year are excluded. Also the exact definition of the full year and of full-time work varies, and the coverage of full-time workers' earnings from second jobs varies (these are excluded in the United Kingdom and probably several other countries, and included in the tax-based statistics from Denmark, while in the United States earnings from both employee and self-employment second jobs are included).

36. An item of technical importance is the coverage of these earnings surveys. Table 7 shows, for a date near 1986, the grossed-up population covered by the earnings statistic, together with annual average employee employment and the part-time share in total employment. The last column shows an estimate of the proportion of the annual average level of full-time dependent employment that is covered. This ratio is normally less than one due to the fact that the statistics in question cover only individuals employed for the full year.

37. In the statistics shown from Japan, the survey totals include part-year employees, and coverage is correspondingly high. In the statistics from France. part-year employment is also included, but employment in local government is not covered, so overall coverage is not exceptionally high. In Sweden and Denmark, coverage is low: in Sweden this appears to be because the published employee earnings statistics from the survey exclude employees with 
entrepreneurial income; in Denmark the tax records themselves have a high coverage but low proportion of those in the tax records are considered as "full-year full-time" workers, probably because of a processing procedure used on the tax records which results in some workers being classified as part-time on the basis that they have significant non-wage and salary income.

\section{COMPARISONS OF THREE ESTIMATES OF ANNUAL AVERAGE EARNINGS}

38. This section undertakes a three-way comparison of estimates of earnings of full-year full-time employees as in Table 5, average earnings per full-time equivalent employee calculated from Tables 1 and 4 , and earnings of the Average Production Worker as in Table 3. In many countries, one or more of the elements in these comparisons was not available on quite the appropriate basis for a direct comparison. For example, some countries lack wage and salary bill data in OECD National Accounts, some lack employee data in OECD Labour Force Statistics, and for some countries part-time employment shares were not available and in some one series but not the other in a comparison was available on a fiscal year basis, etc. Thus comparisons here are on a two-way basis, omitting countries where the comparison could not easily be made. A comparison of the estimates of full-year full-time earnings with full-time equivalent earnings is given in Table 8, a comparison of full-year full-time earnings with Average Production Worker earnings is given in Table 9, and a comparison of full-time equivalent earnings with Average Production Worker earnings (the only one of the comparisons available for many countries in time-series) is given in Table 10.

39. The ratios of full-year full-time earnings from surveys to earnings per full-time equivalent employee at a date near 1986, shown in Table 8 , vary both sides of 100 per cent with a total range of about 20 per cent. The conversion of the estimates in Table 2 onto a full-time equivalent basis does improve the agreement between the two sets of statistics: a regression analysis, covering just the seven countries in Table 9, suggested that the part-time share in employment was a significant variable explaining the cross-country differences between the full-year full-time estimates and wages and salaries per employee (6).

40. The reasons for the remaining differences between these two sources of statistics are not known in full. The inclusion of part-year workers (even at their full-year rate of earnings) in the earnings survey statistics in Japan and France may help explain their relatively low level, while the inclusion of earnings from second jobs (including self-employment earnings) in the survey statistics for the United States may help explain their relatively high level.

41. The second part of Table 8 shows three comparisons through time between survey statistics and earnings per full-time equivalent employee. The ratio of the two, in this rather small sample, seems fairly stable through time.

42. Table 9 compares earnings of full-year full-time workers in the earnings surveys with earnings as used for the Average Production Worker study. In general, the statistics from the economy-wide surveys show relatively higher earnings, as might be expected. 
43. Table 10 shows ratios of earnings per full-time equivalent to earnings as used in the Average Production Worker study. The ratio between the two fell significantly between 1979 and 1983 in Austria, Japan, the Netherlands. It has risen significantly between 1984-5 and 1987 in Sweden and the United States. With some exceptions such as these, the two series generally seem to move together to within a few per cent. In the case of the United States, the earnings level used in the average production worker study is computed from average hourly earnings recorded in a monthly establishment survey . Significant growth in non-hourly forms of pay such as bonuses, lump-sum and deferred payments may explain the faster growth in the full-year full-time earnings data over recent years. The Average Production Worker series is the only one presently available for several countries. Tables 9 and 10 show that this series is of varying reliability as a proxy for aggregate measures of earnings. Both tables demonstrate that it takes lower values than the more aggregate measures. However, the size of the difference varies by country. The differences is in part the result of actual differences between the earnings of production workers and all workers (7), but also reflects differences in the concepts and methods used. Hence, the ratios shown in Tables 9 and 10 cannot be used as a measure of the ratio between production workers' earnings and those of all workers. Nor do changes over time in those ratios in Table 10 necessarily reflect actual changes in the ratio of production workers to all workers' earnings: they could equally reflect differences in the coverage of the two measures: thic appears to be the case for example, for the United States. Thus these tables indicate that the Average Production Worker series should be used with caution as an indicator of overall measures of earnings levels and their trends.

\section{E. SUMMARY AND CONCLUSIONS}

44. Section $B$ of this note argued that the annual basis for measuring earnings can give a good coverage of the economy, across industries and occupations, and across types of earnings, and that this wide coverage is necessary for making valid analyses of the structure of earnings by other variables such as sex or occupation. It also argued that statistics of earnings on a weekly or monthly basis tend to be dependent upon country-specific payment practices, and that a closer approach to definitional consistency across countries is possible when on an annual basis. Thus, while these annual statistics have limitations of their own, they deserve more attention. Four tables of earnings statistics, and three tables making comparisons between different estimates of annual earnings, have been presented.

45. Two types of estimates of annual earnings can be obtained from multi-national sources. One is the earnings of the Average Production Worker as used in analysing taxation systems, and the other is obtained as a calculation from national accounts and labour force statistics, dividing the wages and salary bill by annual average employment. This second concept can be refined by correcting statistics onto an approximate full-time equivalent basis 
using estimates of the part-time share in total employment, which have been given separately.

46. The statistics for earnings of the Average Production Worker shown in Table 2 will be most appropriate for users who do not need historical statistics before 1979, who do need up-to-date statistics covering many countries, and who accept the limitation of coverage to manual manufacturing workers, which is thought to lower the general level of earnings by between 5 and 20 per cent, depending upon country.

47. The statistics for wages and salaries per employee shown in Table 1 are in some cases available in long historical series, but are easily accessed only for 12 countries. They cover all employees, and consistency of definition across countries is reasonable. However, the concept, averaging across full-time and part-time workers, is often not useable. When corrected to a full-time equivalent basis, availability is somewhat reduced and the estimates become dependent upon statistics for part-time employment, which are less consistently defined and less easily available on a multi-country basis. However, the concept of earnings involved seems satisfactory for many purposes.

48. Three tables based upon national statistics have been presented, Table 3 showing national estimates of earnings per full-time equivalent worker and Tables 5 and 6 showing statistics drawn from national sources that record the annual earnings of full-year full-time workers. Not many official estimates on the basis of earnings per full-time equivalent worker are available, and differing interpretations of full-time equivalance seem to exist in Table 3 . Statistics in Tables 5 and 6 also reflect differences in definitions, and although they are available for ten countries, are often not available on a timely basis. Nevertheless, as has been explained earlier these are the only annual earnings statistics that have much potential for analysis by sex, occupation, age, and similar variables. The further development of such statistics in the future could involve increasing the historical and country coverage of the statistics, harmonizing their definitions, and publishing some of the more widely available cross-classifications. 
NOTES

1. See the Employment Outlook 1988, Chapter 5, for an examination of female/male earnings differentials and further references.

2. Bound, Brown, Duncan and Rodgers (1989) in the United States conducted a direct check on accuracy of questionnaire responses, comparing them with the records of the employing company. Errors in some types of reported earnings were found to be very large and the authors conclude that "The data...lead quite clearly to the conclusion that the most valid measure of earnings, at least among the three evaluated in this study, is one based on the preceding calendar year. This measure is much more strongly related to the (company) records than is a measure either of usual (weekly) earnings or of earnings in the preceding pay period. Moreover, unlike the report on usual earnings, the reports on annual earnings are essentially unbiased".

3. The Bureau of Labour Statistics makes standardized estimates of civilian employment for 10 countries ("Comparative Labor Force Statistics for Ten Countries, 1959-1988", mimeo, June 1989) which agree closely with statistics in the OECD Labour Force Statistics. The definitional bases of the employment statistics in the OECD National Accounts are more varied.

4. Rates of part-time working vary sharply across countries and across sectors within countries: the community, social and personal services sector has an incidence over 30 per cent in Norway, Sweden, the Netherlands and the United Kingdom [Employment Outlook (1987), Tables 1.4 and 1.5] while incidences below 10 per cent arise in other sectors, or in other countries.

5. Total manhours worked by employees, by industry sector, are published in the OECD National Accounts for the United States, Finland and Sweden. In 1986, working hours per employee (annual average employment) varied in Finland from 1457 in mining and quarrying to 1806 in private sector community, social and personal services, and in Sweden from 1131 in agriculture, forestry and fishing to 1726 in electricity, gas and water. Total annual working hours per person employed, for employees in 3 countries and for all employment in 5 further countries are published in the 1989 Employment Outlook. Table L. 
6. The regression conducted was

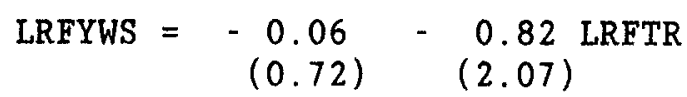

where LRFYWS is the logarithm of the ratio of the Table 5 to the Table 1 estimate of annual earnings, LRFTR is the ratio of full-time to total employment as in Table 3, t-statistics are in brackets, and the countries and dates covered were as in Table 7, Part A. The coefficient on LRFTR suggests that the Table 1 estimate of earnings is lower when the proportion of full-time work in employment is low, as expected.

7. Manufacturing production workers earn less than the overall average: but the difference is not as large as might be imagined - - partly because in many countries women's earnings are relatively low, and women are mainly employed outside manufacturing production. The EEC Structure of Earnings Survey, 1978, found that production workers earnings (including annual bonuses) were 14 per cent lower than the general average within industry in France and the Netherlands, and 5 to 7 per cent lower in Belgium, Denmark, Germany, and Italy (Vassille, 1989, Table 1). The table below suggests that the manufacturing production workers' earnings were 18 per cent lower than the whole-economy average in France and Japan, but only 9 per cent lower in the United Kingdom.

Average earnings by sector and occupations

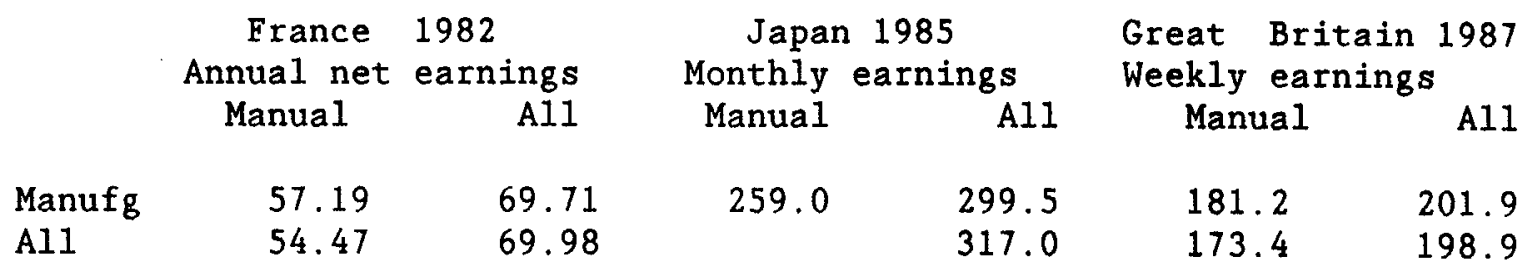

Ratio, manual manufacturing to all 0.82 0.82 0.91

Sources and notes:

France: source as Table 5. Manual and all earnings in manufacturing refer to earnings in NAP industries 7 to 23 , weighted using industry total employment. All industries excludes central and local government: see Annex C.

Japan and Great Britain: as Employment Outlook 1988, Table C.2. 


\section{REFERENCES}

BOUND J., BROWN C., DUNCAN G.J., and RODGERS W.L., (1989), "Measurement Error in Cross-sectional and Longitudinal Labor Market Surveys: Results from Two Validation Studies", NBER Working Paper No. 2884, Cambridge, MA.

MADDISON A., (1982), Phases of Capitalist Development, Oxford University Press.

VASSILLE L.. (1989), "Les ecarts de salaires à l'intérieur de huit pays de la Communauté Européeene", Economie et Statistique, March 1989.

VLASSENKO E., (1981), "La structure des salaires dans I'industrie et les services", Collections de 1'INSEE M 90-91. 
Table 1

Wages and salaries per employee (a)

Austria Canada Finland France Germany Japan

\begin{tabular}{|c|c|c|c|c|c|c|}
\hline 1977 & 151.3 & 13.1 & 33.2 & 45.2 & 25.9 & 2.46 \\
\hline $1978^{\circ}$ & 160.1 & 13.7 & 35.4 & 50.8 & 27.2 & 2.62 \\
\hline 1979 & 166.8 & 14.8 & 39.4 & 57.0 & 28.8 & 2.76 \\
\hline 1980 & 178.3 & 16.2 & 44.6 & 65.5 & 30.7 & 2.92 \\
\hline 1981 & 189.4 & 18.1 & 50.8 & 75.0 & 32.2 & 3.07 \\
\hline 1982 & 190.3 & 20.1 & 55.7 & 85.0 & 33.5 & 3.19 \\
\hline 1983 & 199.1 & 20.8 & 61.6 & 92.7 & 34.7 & 3.26 \\
\hline 1984 & 201.6 & 21.9 & 67.4 & 99.7 & 35.7 & 3.37 \\
\hline 1985 & 212.5 & 22.9 & 72.8 & 105.5 & 36.7 & 3.48 \\
\hline 1986 & 222.4 & 23.7 & 78.1 & 109.7 & 38.1 & 3.58 \\
\hline \multirow[t]{2}{*}{1987} & 230.0 & 24.8 & 85.8 & 113.1 & 39.2 & 3.67 \\
\hline & \multicolumn{2}{|c|}{$\begin{array}{l}\text { Netherlands } \\
\text { Norway }\end{array}$} & Spain & Sweden & $\begin{array}{r}\text { United } \\
\text { Kingdom }\end{array}$ & $\begin{array}{l}\text { United } \\
\text { States }\end{array}$ \\
\hline 1977 & 29.9 & 62.1 & & 49.0 & 3.31 & 11.9 \\
\hline 1978 & 32.1 & 66.8 & & 53.1 & 3.76 & 12.9 \\
\hline 1979 & 33.9 & 68.7 & & 57.5 & 4.33 & 14.0 \\
\hline 1980 & 34.9 & 77.2 & 754.9 & 63.1 & 5.18 & 15.3 \\
\hline 1981 & 35.0 & 85.1 & 866.7 & 68.3 & 5.84 & 16.6 \\
\hline 1982 & 36.5 & 94.7 & 984.1 & 72.6 & 6.36 & 17.7 \\
\hline 1983 & 36.6 & 102.1 & 1117.8 & 78.0 & 6.90 & 18.4 \\
\hline 1984 & 36.6 & 110.1 & 1251.0 & 85.6 & 7.30 & 19.4 \\
\hline 1985 & 37.0 & 117.8 & 1342.7 & 92.4 & 7.83 & 20.3 \\
\hline 1986 & 37.9 & 129.6 & 1445.7 & 100.1 & 8.46 & 21.0 \\
\hline 1987 & 38.3 & 140.7 & & 110.8 & & 22.0 \\
\hline
\end{tabular}

\section{Note:}

a) Currency units used are listed in Annex A. Statistics are total wages and salaries divided by employment, usually the annual average level of employment.

Sources: OECD National Accounts and OECD Labour Force Statistics computer data files. 
Table 2

\section{Earnings of the Average Production Worker (a)}

Australia Austria Belgium Canada Denmark Finland France Germany

(b) (c)

$\begin{array}{rrrrrrrrr}1979 & 11.6 & 136.0 & 463.3 & 15.0 & 103.1 & 38.3 & 45.4 & 29.7 \\ 1980 & & & & & & & & \\ 1981 & 15.5 & 155.6 & 546.8 & 18.3 & 122.3 & 48.8 & 59.0 & 32.9 \\ 1982 & & & & & & & & \\ 1983 & 17.6 & 172.7 & 609.6 & 21.0 & 145.0 & 59.0 & 73.1 & 35.4 \\ 1984 & 18.8 & 180.7 & 638.9 & 22.3 & 152.1 & 65.1 & 78.6 & 36.5 \\ 1985 & 20.3 & 191.2 & 649.5 & 23.4 & 159.7 & 70.3 & 83.2 & 37.6 \\ 1986 & 21.4 & 199.6 & 658.7 & 24.1 & 167.3 & 74.6 & 87.0 & 38.9 \\ 1987 & 22.7 & 205.4 & 674.3 & 24.7 & 180.4 & 80.0 & 90.1 & 40.1 \\ 1988 & 24.9 & 213.4 & 682.8 & 25.9 & 189.4 & 87.1 & 93.4 & 41.8 \\ & & & & & & & \\ & \text { Greece } & \text { Ireland } & \text { Italy } & \text { Japan } & \text { Netherlands } & \text { New } \\ & & & & \text { Luxembourg } & \text { Norway } & \text { Zealand } \\ 1979 & 165.0 & 4.43 & 6.5 & 2.33 & 480.5 & 31.5 & 74.1 & 9.6 \\ 1980 & & & & & & & & \\ 1981 & 256.8 & 6.03 & 9.9 & 2.67 & 547.1 & 34.2 & 89.8 & 13.2 \\ 1982 & & & & & & & & \\ 1983 & 401.7 & 7.61 & 13.0 & 2.87 & 615.4 & 37.7 & 107.8 & 15.0 \\ 1984 & 503.1 & 8.44 & 14.7 & 2.99 & 656.6 & 38.3 & 116.7 & 16.0 \\ 1985 & 621.0 & 9.04 & 16.7 & 3.10 & 676.3 & 39.0 & 125.7 & 17.8 \\ 1986 & 817.0 & 9.65 & 17.7 & 3.16 & 692.0 & 39.7 & 138.4 & 19.2 \\ 1987 & 892.6 & 10.16 & 19.1 & 3.22 & 707.0 & 40.4 & 150.2 & 22.4 \\ 1988 & 1111.4 & 10.69 & 20.4 & 3.31 & 727.0 & 41.4 & 159.0 & 26.2\end{array}$

Portugal Spain Sweden Turkey United United

$$
\text { Switzerland Kingdom States }
$$

$\begin{array}{llllllll}1979 & 139.1 & 559.0 & 64.0 & 30.0 & 0.17 & 4.91 & 13.9 \\ 1980 & & & & \end{array}$

$\begin{array}{llllllll}1981 & 196.7 & 748.7 & 76.7 & 33.7 & 0.45 & 6.10 & 16.5\end{array}$

$\begin{array}{lrrrrrrr}1983 & 280.3 & 939.7 & 87.6 & 37.5 & 0.71 & 7.07 & 18.4\end{array}$

$\begin{array}{lrrrrrrr}1984 & 359.0 & 1034.5 & 96.2 & 38.3 & 0.98 & 7.96 & 19.3\end{array}$

$\begin{array}{llllllll}1985 & 402.5 & 1155.1 & 103.9 & 39.5 & 1.37 & 8.55 & 20.0\end{array}$

$\begin{array}{llllllll}1986 & 446.8 & 1283.7 & 110.5 & 40.9 & 1.64 & 9.12 & 20.5\end{array}$

$\begin{array}{rrrrrrrr}1988 & 623.4 & 1376.2 & 118.1 & 42.1 & 2.60 & 9.79 & 21.0\end{array}$

Notes:

a) Generally the estimated annual earnings of a full-time production worker in manufacturing. See the original sources for more detailed

b) information on the estimates than can be given here.

Non-managerial employees. Estimates refer to the fiscal year (July of
year to following June).

c) Men only .

d) Fiscal year (April of year to the following March).

e) All employees. Fiscal year (April of year to following March).

f) Fiscal year (April of year to following March).

Sources: The Tax/Benefit Position of Production Workers. 1979-1984 (OECD, 1986) and ibid., 1984-1987 (OECD 1988). 

National estimates of employee earnings per full-time equivalent employee or per labour unit

Italy $\underset{\text { Zealand }}{\text { New }}$ Norway

$\begin{array}{rrrr}1977 & 7.0 & & \\ 1978 & 8.2 & & \\ 1979 & 9.8 & & \\ 1980 & 11.9 & & \\ 1981 & 14.6 & & \\ 1982 & 17.0 & & 102.3 \\ 1983 & 19.7 & & 111.5 \\ 1984 & 22.1 & & 120.1 \\ 1985 & 24.3 & 17.5 & 129.1 \\ 1986 & 26.1 & 20.7 & 141.8 \\ 1987 & 28.5 & 23.2 & 155.4 \\ 1988 & 31.0 & 25.4 & 164.6\end{array}$

\section{Notes by country:}

Italy: Labour units are estimated considering employment in a regular job as a single unit and converting employment in irregular and second jobs and work by people who do not consider themselves employed onto this basis.

New Zealand: Estimates computed as 52.14 times the average weekly earnings reported from four successive Quarterly Employment Surveys. Statistics relate to aggregate earnings of survey units divided by full-time equivalent employment, which is computed giving part-time employment a half weight.

Norway: Average wages in cash per person-year, on the basis of person-year estimates which are given in Norwegian national accounts.

Sources: Italy: Conti Economici Nazionali, collana d'informazione 1988 no. 23 and 1989 no. 15 . New Zealand: Communication from the New Zealand Department of Statistics. Norway: Lonns-statistikk 1988, Table 1. 
Table 4

The share of part-time employment in total employment (a)

Australia Austria $\stackrel{\text { Belgium }}{\text { Canada }} \underset{\text { Finland }}{\text { France }}$ Germany Ireece

\begin{tabular}{rrrrrrrrrrr}
\hline 1977 & 15.0 & 7.0 & 6.1 & 11.7 & 22.0 & 6.1 & 8.7 & 11.7 & & 7.2 \\
1978 & 16.0 & 7.2 & & 12.1 & & 6.2 & 7.8 & & \\
1979 & 15.9 & 7.6 & 6.0 & 12.5 & 22.7 & 6.7 & 8.2 & 11.4 & 5.1 \\
1980 & 16.4 & 7.5 & & 13.0 & & 6.7 & 8.3 & & & \\
1981 & 16.5 & 7.6 & 6.4 & 13.5 & 23.7 & 7.4 & 8.3 & 12.0 & 3.3 & \\
1982 & 17.1 & 7.9 & & 14.4 & & 7.7 & 9.2 & & & \\
1983 & 17.5 & 8.3 & 8.4 & 15.4 & 23.8 & 8.3 & 9.7 & 12.6 & 6.5 & 6.6 \\
1984 & 17.8 & 7.3 & 8.0 & 15.4 & 21.1 & 8.3 & 10.3 & 12.3 & 4.9 & 6.0 \\
1985 & 18.2 & 7.4 & 8.6 & 15.5 & 24.3 & 8.2 & 10.9 & 12.8 & 5.3 & 6.5 \\
1986 & 18.9 & 7.1 & 9.4 & 15.6 & 23.7 & 8.1 & 11.7 & 12.9 & 5.8 & 6.2 \\
1987 & 20.0 & 8.6 & 9.9 & 15.2 & 24.2 & 8.0 & 11.8 & 12.7 & 5.5 & 7.1 \\
1988 & 20.1 & & & 15.4 & & & 12.0 & & 5 & \\
\hline
\end{tabular}

Japan Netherlands New Norway Sweden United United

Italy Luxembourg Zealand Kingdom States

\begin{tabular}{llllllllll}
\hline 1977 & 5.9 & 14.4 & 5.0 & 17.3 & 12.4 & 27.1 & 21.6 & 17.2 & 16.7 \\
1978 & & 14.7 & & 17.7 & 12.9 & 26.5 & 22.7 & & 16.5 \\
1979 & 5.3 & 15.4 & 5.8 & 18.2 & 13.3 & 27.3 & 23.6 & 16.4 & 16.4 \\
1980 & & 15.7 & & 18.8 & 13.4 & 27.0 & 24.2 & & 16.9 \\
1981 & 5.1 & 15.6 & & 19.7 & 13.9 & 28.6 & 24.7 & 17.9 & 17.1 \\
1982 & & 15.9 & & 20.9 & 14.2 & 29.0 & 25.0 & & 18.2 \\
1983 & 4.6 & 16.2 & 6.3 & 22.2 & 14.6 & 29.8 & 24.8 & 19.0 & 18.4 \\
1984 & 5.5 & 16.4 & 5.5 & 23.8 & 15.1 & 29.4 & 24.6 & 20.9 & 17.6 \\
1985 & 5.3 & 16.5 & 6.8 & 24.0 & 15.6 & 28.6 & 24.0 & 21.2 & 17.5 \\
1986 & 5.0 & 16.7 & 6.7 & 24.7 & 16.0 & 28.7 & 23.5 & 21.6 & 17.4 \\
1987 & 5.6 & 16.6 & 7.1 & 25.1 & 17.1 & 28.6 & 25.1 & 21.9 & 17.3 \\
1988 & & & & & 18.0 & 28.6 & & & \\
\hline
\end{tabular}

\section{Note:}

a) Definitions of part-time work vary across countries. Estimates include self-employment except for the Netherlands and New Zealand. Data shown are generally based on statistics as published, which in several cases are affected by changes in definition. However statistics for years the Netherlands prior to 1984 and for Austria after 1984 are chain-1inked estimates. See the source for more detailed notes.

Source: Secretariat data base drawn from national sources as described in the Employment Outlook 1989, Annex 1.B. 
Table 5

Average annual earnings of full-year full-time workers (a)

Australia Canada Denmark Netherlands

\begin{tabular}{|c|c|c|c|c|c|}
\hline $\begin{array}{l}1983 \\
1984 \\
1985 \\
1986\end{array}$ & 22.1 & 26.4 & $\begin{array}{l}161.8 \\
169.4 \\
187.5\end{array}$ & $\begin{array}{l}44.1 \\
45.1\end{array}$ & 120.4 \\
\hline & Finland & France & Japan & $\begin{array}{l}\text { United } \\
\text { Kingdom }\end{array}$ & $\begin{array}{l}\text { United } \\
\text { States }\end{array}$ \\
\hline 1977 & 35.5 & & & & \\
\hline 1978 & 38.2 & 47.8 & & 4.33 & \\
\hline 1979 & 42.7 & & & & 16.3 \\
\hline 1980 & 47.6 & 61.3 & & & 17.7 \\
\hline 1981 & & & & & 19.2 \\
\hline 1982 & 59.8 & 79.1 & 3.02 & & 20.5 \\
\hline 1983 & 66.6 & & & & 21.2 \\
\hline 1984 & 72.4 & 95.6 & & & 22.4 \\
\hline 1985 & & & & & 23.8 \\
\hline 1986 & 85.2 & 108.2 & & & 24.9 \\
\hline 1987 & 91.8 & & 3.60 & & 25.7 \\
\hline
\end{tabular}

\section{Notes:}

a) Statistics are actual annual earnings reported by or in respect of a certain sample of individuals, except for some individuals covered (part-year employed or with pay affected by absence) in France, Japan and the Netherlands as detailed below. The population covered always excludes part-time workers and the self-employed, but in other respects coverages and concepts of earnings applied vary as described below and in Annex C.

Australia. July 1985-June 1986 (tax year). Full-year is defined as 50-52 weeks employed. Full-time is defined as 35 or more hours per week.

Canada. Full-year full-time is defined as 49-52 weeks employed and mostly working 30 hours or more per week.

Denmark. Full-year full-time is defined as at least 11 months employed for at least 30 hours a week. However the computer-based classification system classifies some persons as part-time employed on the basis that they have income from different sources (wages, pensions, etc). (Communication from Danmarks Statistik).

Finland. Full-year is defined as 12 months employed. 
Table 5 (notes, cont.)

Erance. Part-year full-time employees are included at an equivalent annual rate. Data cover employment in private and semi-public sectors and central government, excluding local government. Earnings refer to gross wages and salaries (whereas national publications usually give statistics net of employee social security contributions).

Japan. The survey takes place in October, and asks for annual earnings, including estimates of annual earnings from those who have not been employed the whole year. Thus the reference period is not exact. Full-year refers to employees who have worked 200 days or more over the year. Employees who have worked less than a full year are included on the basis of their expected working days and annual earnings for a full year. Employees with temporary and daily contracts are included: "arubaito" (student and similar workers) are excluded along with part-timers.

Netherlands. Earnings of full-year workers whose pay was affected by absence are reported on a 'normal' basis.

Sweden. Full-year full-time is defined at least 90 per cent of the normal paid annual working hours for the employee's workplace. Excludes employees with entrepreneurial incomes.

United Kingdom. April 1978-March 1979 (tax year). Results relate to employees who were continuously employed with the same employer from April 1978 to April 1979, and who were normally expected to work 30 or more hours per week ( 25 hours for teachers) or who had no specified normal hours but were regarded as full-time by their employer.

United States. Full-year is 50 to 52 weeks.

b) Although Germany is not included in this table, data are available from social security sources supplemented by information from employers. These cover employees including apprentices, but exclude Beamte (established civil servants) who are about half of employment in government and social security administration and 10 per cent of all employees. Average annual earnings, which take into account only earnings up to the social security contribution limit for the 7 to 8 per cent of employees whose true earnings are above this limit, were 40.035 $\mathrm{DM}$ in 1985 and $41,533 \mathrm{DM}$ in 1986 [Statistisches Bundesamt (1989). Entgelt und Beschäftigungsdauer der Arbeitnehmer 1985 und 1986 (Bevölkerung und Erwerbstätigkeit, Fachserie 1 Reihe 4.2.2)]. In these statistics, full-year includes only employees who did not change job during the year. Workers with contractual weekly hours below the normal level for the industry or employer are classified as part-time (about 17 per cent of full-year workers).

Source: See Annex C. 
Table 6

Average annual earnings of full-year full-time workers by sex (a)

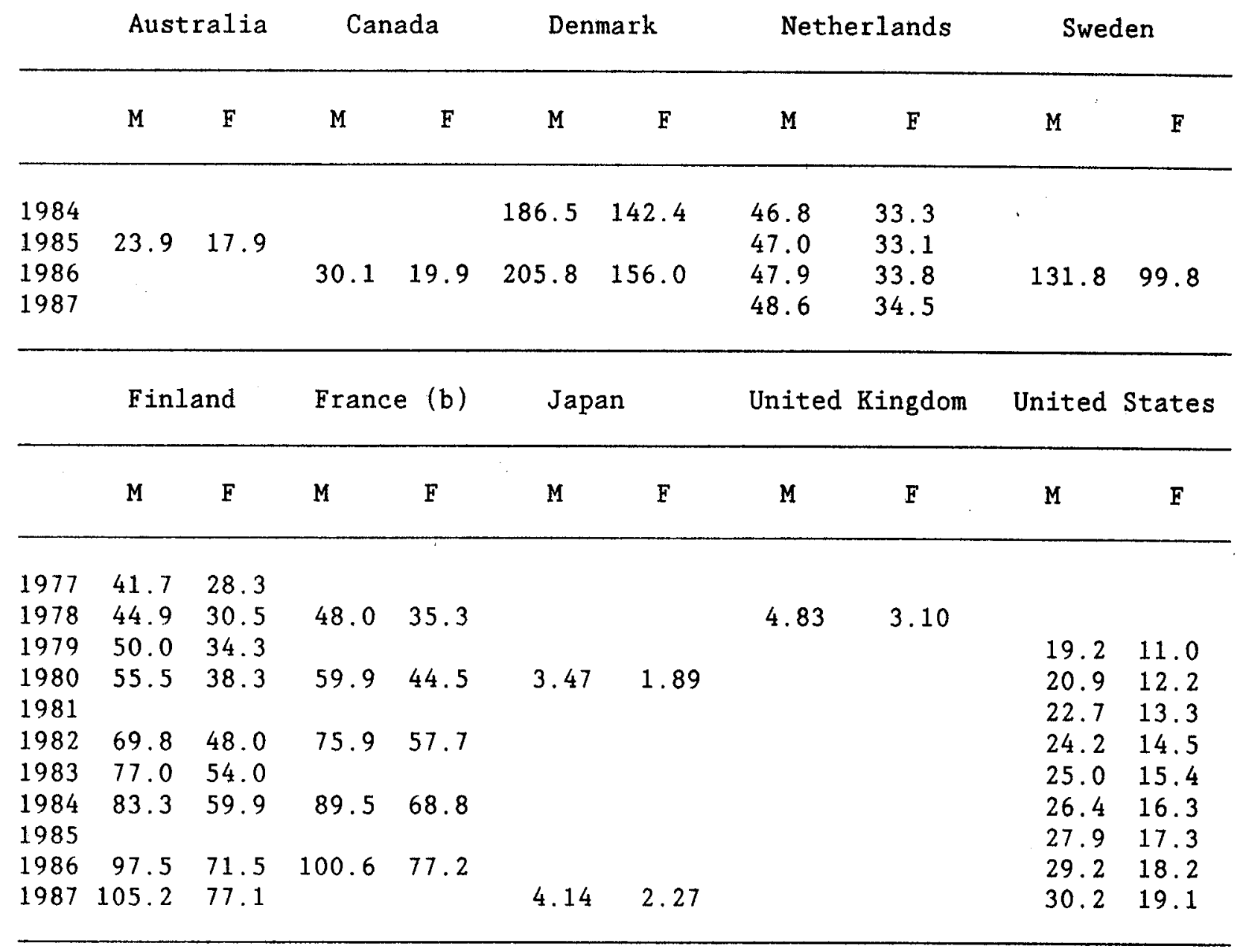

\section{Notes:}

a) For notes, see table 5 .

b) In France, data for men and women are shown net of employee social security contributions as in national publications.

Source: See annex C. 
Table 7

Coverage of survey statistics of earnings reported in Table 5

$\begin{array}{cllll}\text { Earnings } & \text { Numbers } & \text { Annual } & \text { Part-time } & \text { Estimated } \\ \text { Year } & \text { of full- } & \text { average } & \text { share } & \text { coverage of } \\ \text { year full- } & \text { level of } & \text { in } & \text { of full-time } \\ \text { time workers employee } & \text { employment } & \text { employment } \\ \text { (in Table 5) } & \text { employment } & \text { (per cent) } & \text { (per cent) }\end{array}$

(1)

(2)

(3)

(4)

\begin{tabular}{lcrrrr}
\hline Australia & $1985-6$ & 4161 & 5583 & 18.2 & 91.1 \\
Canada & 1986 & 8137 & 10469 & 15.6 & 92.1 \\
Denmark & 1986 & 1354 & 2324 & 23.7 & 76.4 \\
Finland & 1987 & 1567 & 2041 & 8.0 & 83.4 \\
France & 1986 & 13439 & 17642 & 11.7 & 86.3 \\
Japan & 1987 & 36880 & 44280 & 16.6 & 99.9 \\
Sweden & 1986 & 2251 & 3989 & 23.5 & 73.7 \\
United States & 1986 & 68686 & 99847 & 17.4 & 83.3 \\
\hline
\end{tabular}

Notes and sources by column:

1) On a grossed-up survey basis from sources as for Table 5 .

2) From OECD Labour Force Statistics: statistics for Australia refer to

3) As in Table 4 .

4) C1 divided by $(\mathrm{C} 2 \mathrm{x}(1-\mathrm{C} 3 / 100))$, where $\mathrm{C} 1-\mathrm{C} 3$ are columns (1) to (3). 
Comparisons of earnings estimates for the full-year full-time worker and for wages and salaries per full-time equivalent employee

A. Point-in-time comparisons

$\begin{array}{cclll}\begin{array}{c}\text { Year } \\ \text { of }\end{array} \text { full-year } & \text { Wages and } & \text { Part-time } & \text { Wages and } \\ \text { earnings earnings } & \text { per } & \text { in } & \text { salaries } \\ & & \text { employee employment } & \text { per full-time } \\ & \text { (currency) } & \text { (currency) } & \text { (per cent) } & \text { (currency) }\end{array}$

(3)

(4)
(1)

(2)

$\begin{array}{rrr}1986 & 26.40 & 23.69 \\ 1987 & 91.80 & 85.80 \\ 1986 & 108.19 & 109.65 \\ 1987 & 3.60 & 3.67 \\ 1986 & 45.10 & 37.88 \\ 1986 & 120.37 & 100.10 \\ 1986 & 24.86 & 21.01\end{array}$

23.69

Canada

Finland

France

Japan

Netherlands

Sweden

United States 1986
Ratio of full-year full-time to full-time equivalent (per cent)

(5)

B. Time-series on the basis of column (5) above, three countries

$\begin{array}{llll}\text { Earnings } & \text { United } \\ \text { date Finland France Japan States }\end{array}$

$\begin{array}{lllll}1977 & 103.8 & & & \\ 1978 & 104.7 & 90.4 & & \\ 1979 & 104.8 & & & 106.9 \\ 1980 & 103.3 & 89.7 & & 106.0 \\ 1981 & & & & 105.5 \\ 1982 & 103.3 & 88.8 & 87.1 & 105.4 \\ 1983 & 103.5 & & & 104.6 \\ 1984 & 102.9 & 91.0 & & 105.6 \\ 1985 & & & & 106.8 \\ 1986 & 104.6 & 92.9 & & 108.0 \\ 1987 & 102.6 & & 90.2 & 106.8\end{array}$

\section{Notes and sources by column:}
1) As in Table 5 .
2) As in Table 1 .
3) As in Table 4.
4) Calculated as $\mathrm{C} 2 /\left(1-0.5{ }^{*} \mathrm{C} 3 / 100\right)$, where $\mathrm{C} 2-\mathrm{C} 3$ are columns 2 and 3 .
5) Ratio of column (1) to column (4), in per cent. 
Table 9

\section{Comparisons of earnings estimates for the full-year full-time worker and for the Average Production Worker (a)}

\begin{tabular}{|c|c|c|c|}
\hline $\begin{array}{l}\text { Year } \\
\text { of } \\
\text { arnings }\end{array}$ & $\begin{array}{l}\text { Full-year } \\
\text { full-time } \\
\text { earnings }\end{array}$ & $\begin{array}{l}\text { Earnings } \\
\text { of the } \\
\text { Average } \\
\text { Production } \\
\text { Worker } \\
\text { (currency) }\end{array}$ & $\begin{array}{l}\text { Ratio, full- } \\
\text { year full-time } \\
\text { to Average } \\
\text { Production } \\
\text { Worker } \\
\text { (per cent) }\end{array}$ \\
\hline
\end{tabular}

(1)

(2)

(3)

$\begin{array}{lcrrl}\text { Australia } & 1985-6 & 22.14 & 20.27 & 109.2 \\ \text { Canada } & 1986 & 26.40 & 24.13 & 109.4 \\ \text { Denmark } & 1986 & 187.50 & 167.30 & 112.1 \\ \text { Finland } & 1987 & 91.80 & 80.04 & 114.6(\mathrm{~b}) \\ \text { France } & 1986 & 108.19 & 86.97 & 124.4 \\ \text { Japan } & 1987 & 3.60 & 3.22 & 112.1 \\ \text { Netherlands } & 1986 & 45.10 & 39.70 & 113.6 \\ \text { Sweden } & 1986 & 120.37 & 110.45 & 109.0 \\ \text { United States } & 1986 & 24.86 & 20.50 & 121.3(\mathrm{~b})\end{array}$

\section{Notes:}

a) Average Production Worker earnings are used by the OECD as an indicator of the general level of earnings when making typical-case calculations of tax and benefit rates. Sources and methods for Average Production Worker earnings reported in this table differ from those for full-year full-time earnings. This table therefore illustrates the importance of differences in source and method for earnings estimates, and does not attempt to estimate the earnings of manufacturing production workers relative to other workers on a common or comparable basis.

b) The Finland ratio as in column (3) was close to 112 per cent from 1979 to 1984, and then rose; while the United States ratio in that column was close to 116 per cent over 1979-1984, then rose to 122 per cent in 1987.

Sources: Tables 2 and 5. 
Table 10

Ratio between the earnings estimates for wages and salaries per ful1-time equivalent employee and for the Average Production Worker (a)

\begin{tabular}{|c|c|c|c|c|c|c|c|c|c|c|}
\hline & Austri & & Finland & & ermany & & therlan & dds & Sweden & United \\
\hline & & Canada & & France & & Japan & & Norway & & States \\
\hline $\begin{array}{l}1979 \\
1980\end{array}$ & 127.5 & 105.8 & 106.6 & 131.0 & 102.7 & 128.5 & 118.4 & 107.4 & 102.0 & 109.2 \\
\hline $\begin{array}{l}1981 \\
1982\end{array}$ & 126.5 & 106.1 & 108.1 & 132.5 & 104.1 & 124.6 & 113.4 & 110.6 & 101.6 & 110.3 \\
\hline 1983 & 120.2 & 107.3 & 108.8 & 133.2 & 104.6 & 123.5 & 109.3 & 111.3 & 101.7 & 110.6 \\
\hline 1984 & 115.8 & 106.2 & 108.0 & 133.8 & 104.2 & 122.9 & 108.5 & 110.5 & 101.5 & 109.8 \\
\hline 1985 & 115.4 & 106.3 & 107.9 & 134.1 & 104.3 & 122.2 & 107.8 & 109.3 & 101.1 & 111.4 \\
\hline 1986 & 115.5 & 106.5 & 109.2 & 133.9 & 104.8 & 123.7 & 108.9 & 109.3 & 102.7 & 112.3 \\
\hline 1987 & 117.0 & 108.7 & 111.7 & 133.3 & 104.3 & 124.3 & 108.3 & 109.3 & 107.3 & 114.5 \\
\hline
\end{tabular}

\section{Note:}

a) See note (a) in Table 9 .

Sources: Tables 1,2 and 4. 


\section{Annex A}

\section{Currency units used in Tables \\ Scale Currency}

\begin{tabular}{|c|c|c|}
\hline Australia & Thousands & Dollars \\
\hline Austria & Thousands & Schillings \\
\hline Belgium & Thousands & Francs \\
\hline Canada & Thousands & Dollars \\
\hline Denmark & Thousands & Kroner \\
\hline Finland & Thousands & Markaa \\
\hline France & Thousands & Francs \\
\hline Germany & Thousands & Marks \\
\hline Greece & Thousands & Drachma \\
\hline Ireland & Thousands & Pounds \\
\hline Italy & Million & Lire \\
\hline Japan & Million & Yen \\
\hline Luxembourg & Thousands & Francs \\
\hline Netherlands & Thousands & Guilder \\
\hline New Zealand & Thousands & Dollars \\
\hline Norway & Thousands & Kroner \\
\hline Portugal & Thousands & Escudos \\
\hline Spain & Thousands & Pesetas \\
\hline Sweden & Thousands & Kroner \\
\hline Switzerland & Thousands & Francs \\
\hline Turkey & Million & Liras \\
\hline United Kingdom & Thousands & Pounds \\
\hline United States & Thousands & Dollars \\
\hline
\end{tabular}




\section{Annex B}

\section{Concepts and definitions in annual statistics of employment and earnings}

\section{Links with national accounts and labour force statistics}

1. The concepts and definitions used in statistics of annual employment and earnings can be considered in terms of individual earnings histories. To provide an estimate of employee employment in the sense of labour force statistics and of wages and salaries in the sense of the national accounts, weeks of employment and wages and salaries earned during the reference year must both be recorded for a representative sample of the population, including individuals who were not employees at the survey date. To provide estimates of full-time equivalence, a split of employees into full-time/part-time status over the year is needed: and it is useful to imagine that information on annual hours of work is also available.

\section{Concepts of annual earnings and annual hours worked}

2. Concepts of annual earnings, employment and hours in current use can be derived from estimates of economy-wide numbers and averages broken down between full-year and part-year and full-time and part-time employees as in Table B.1. Filling this table involves recording 12 detailed items NYF, WYF etc, from which the other items can be derived. Of these 12 items, two are known almost a priori: weeks of work for full-year employees (WYF, WYP) are by definition close to 52 .

3. Using this table, among the statistics that can be derived are:

\section{Employment}

Total number of persons

who were employees during the year

Annual average employment

Full-time equivalent employment NFE

$$
\begin{aligned}
= & N \\
= & N^{*} W / 52 \\
= & \left(N Y * W Y+N{ }^{*} W U\right) / 52 \\
= & \left(N Y F+W Y F+N U{ }^{*} W U F+\right. \\
& \left.N Y{ }^{*} W Y P+N U P * W U P\right) / 52 \\
= & \left(N Y F{ }^{*} W Y+N U{ }^{*} W U F+\right. \\
& \left.S^{*}(N Y P * W Y P+N U P * W U P)\right) / 52
\end{aligned}
$$

(where $S$ is the relative weight of part-time work - - which may be set arbitrarily at 0.5 , or be computed from relative hours of work of part-time workers)

Number of full-year employed $=\mathrm{NY}$

Number of full-year full-time employed $\quad=$ NYF 
Total earnings

Total wages and salaries

TWS

$=\quad N^{*} E$

Average earnings

Total wages and salaries

per average employee

Total wages and salaries

per full-time equivalent employee

Earnings of full-year

full-time employees

$=$ TWS $/$ NAA

$=\quad$ TWS $/ \mathrm{NFE}$

$=\quad \mathrm{EYF}$

Measures of total and of average annual hours can be defined in exactly the same way as for earnings.

4. The definitions above can be used to show that annual average employment (NAA) is less than the total number of persons with earnings (N), and greater than the number of full-year workers NY (assuming the weeks of full-year workers are 52). The definitions also show that annual average employment (NAA) is a concept on a full-year equivalent but not a full-time equivalent basis: this explains why it is rarely, if ever, used for tabulating survey information on earnings or other income information. Preference is given to the bases of all persons with earnings (N) or full-year full-time earners (NYF), which are simple head-counts and thus conceptually amenable to cross-classification. Thus, definitional discrepancies between the employment concepts used in tabulating earnings data and those used in tabulating labour force data seem likely to continue.

5. If possible, statistics of average annual earnings should be on the same definitional basis as statistics of average annual hours. Two concepts of annual average hours of work are currently in use. First, debates about work-time (notably in Germany which has low annual hours and Japan which has long hours) have cited estimates of hours on the conceptual basis of the annual hours of a full-year full-time worker (1). Second, estimates of average annual hours as published in the Employment Outlook 1989 (Table L) are, in principle, on the basis of total hours worked divided by annual average employment. Madison (1982) estimated annual hours on this conceptual basis for a large number of countries. This definition is ideal for estimation of total hours worked in the economy: but it does not measure actual average annual hours for any given individuals. It may be conceptually inappropriate when, for example, reporting annual hours of work in seasonal as compared with non-seasonal industries, for which purpose a third definition would be needed (2). A fourth definitional basis, annual hours divided by full-time equivalent employment, is not generally used since it would by definition be similar or equal to the working hours of the standard equivalent unit (i.e. the full-year full-time worker).

\section{Concepts of earnings and hours implemented for Australia, 1985-6}

6. In order to investigate. how much these definitional issues matter in practice, Table B.2 implements the framework of Table B.1 for Australia, 1985-6, with a breakdown by sex. It should be noted that annual hours reported here are not an accurate estimate of actual hours: the hours have been computed as weeks employed times average weekly hours of work, and the statistics may include paid holidays (since average weekly hours refer to weeks without a holiday) and be affected by mis-reporting (since documentation is rarely available to survey respondents). The annual hours are reported on this basis for illustrative purposes. 
7. Some features of the statistics in Table B. 2 are:

i. Full-year employees are only 70 per cent of the total of persons who were employed at some time during the year. However, because part-year employees averaged 28 weeks of employment, full-year employees account for 85 per cent of annual average employment.

ii. Part-year and part-time work are both more frequent for women than for men.

iii. Part-year and part-time work are associated: part-time workers average fewer weeks employed, and part-year workers average fewer hours of work per week, than their full-time or full-year counterparts.

iv. Average hourly earnings (i.e. average earnings divided by average hours) are less for part-year than for full-year earners: for male full-timers, the shortfall is nearly 20 per cent.

v. Average hourly earnings of part-time workers are (controlling for sex and full-year status) higher than for full-time workers. This result is at variance with usual findings. It may reflect inaccurate recording of hours worked, especially for part-year workers: but for full-year workers the result appears largely to reflect the wider coverage of this survey, compared with employer-based earnings surveys. A significant proportion of full-year part-time wage and salary earnings are payments that individuals receive from their own incorporated company, and if these are excluded, part-time hourly earnings fall back below full-time.

8. Table B.3 presents statistics derived from Table B.2. Within the table, the statistics which according to the discussion given above are on a frequently-used conceptual basis are shown in bold. Some further features are:

i. Persons employed during the year are about 12 per cent (for men) and 22 per cent (for women) higher, and full-year employment is about 14 per cent (for men) and 26 per cent (for women) lower, than average annual employment.

ii. Annual earnings are considerably higher on any full-time basis than they are on other bases, especially for women.

iii. Earnings per full-time equivalent employee are 3 to 5 per cent lower than the average earnings of full-year full-time employees, if full-time equivalent employment is estimated on the basis that part-time work is equivalent to half a full-time employment. This difference is reduced if an hours-based measure of full-time equivalence is used.

iv. There are sharp differences in annual hours worked according to the definition adopted. Average annual hours for persons with any hours are about 14 per cent lower, and average annual hours for full-year ful1-time workers are about 13 per cent higher, than hours on the widely-used basis of total annual hours divided by average annual employment. 
v. The slight difference (about 1 per cent) between annual hours on the basis of total hours divided by full-time equivalent employees (hours-based), and hours of full-year full-time workers, reflects a difference in the standard equivalent unit. The standard unit is the average hours of full-time workers including part-year workers in the first case, but excluding them in the second.

9. This brief study indicates that a variety of concepts of employment, earnings and hours are in common use, and that the choice of definitional basis can significantly affect the level of the reported statistics. This issue is important particularly because some of the definitional bases (e.g. annual average, full-time equivalent, full-year full-time workers only) are conceptually appropriate and in common use for measuring some of the three variables employment, earnings and hours, but not others.

\section{Notes to Annex B}

1. See the ILO World Labour Report III (1987), Table 2.3. The estimates of annual hours cover 15 OECD countries, and are estimated from data on average weekly normal hours, days of annual leave and national holidays, and adjustments for absenteeism. Sources cited are the Bundesvereinigung der Deutschen Arbeitgebervände and Institute der Deutschen Wirtschaft. The Japan Ministry of Labour estimates annual working hours on a similar basis for five countries (for 1986 estimates see Tadashi Nakamura, Ministry of Labour (1988), Labour in Japan Q\&A, pp158-159).

2. Consider the example of two sectors of the economy (or two countries). In sector 1 , all workers work 12 months of 150 hours per month. In sector 2, work is seasonal, and all workers work 6 months of 150 hours per month, spending the other 6 months of the year unemployed or out of the labour force. Annual average working hours, defined as total annual working hours divided by the annual average level of employment, are 1800 in both sectors, even though everyone who works in sector 2 works only 900 hours per year. To reflect the seasonality of work in sector 2 , an appropriate basis for statistics would be total working hours divided by the number of persons with any employment during the year. 
Table B.1

A framework for statistics of annual earnings and hours

\begin{tabular}{|c|c|c|c|}
\hline Number & $\begin{array}{l}\text { Average } \\
\text { weeks } \\
\text { employed }\end{array}$ & $\begin{array}{l}\text { Average } \\
\text { annual } \\
\text { earnings }\end{array}$ & $\begin{array}{l}\text { Average } \\
\text { annual } \\
\text { hours }\end{array}$ \\
\hline
\end{tabular}

All employees

$\mathrm{N}$

W

E

$\mathrm{H}$
Full-year employees
of which mainly full-time mainly part-time

NY

WY

EY

HY

NYF

NYP

WYF

WYP

HYF

HYP

Part-year employees

NU

WU

EU

HU

of which mainly full-time

mainly part-time

NUF

NUP

WUF

WUP

EUF

HUF

HUP 
Table B. 2

Employment, weeks worked, earnings and hours by work intensity, Australia 1985-6

\begin{tabular}{|c|c|c|c|}
\hline Number & $\begin{array}{l}\text { Average } \\
\text { weeks } \\
\text { employed }\end{array}$ & $\begin{array}{c}\text { Average } \\
\text { annual } \\
\text { earnings }\end{array}$ & $\begin{array}{l}\text { Average } \\
\text { annual } \\
\text { hours }\end{array}$ \\
\hline
\end{tabular}

Men

$(\$)$

$\begin{array}{rrrrr}\text { All employees } & 4015 & 46.30 & 19903 & 1923 \\ \text { Full-year employees } & 3068 & 51.96 & 23302 & 2204 \\ \text { of which mainly full-time } & 2933 & 51.96 & 23905 & 2266 \\ \text { mainly part-time } & 135 & 51.86 & 10192 & 864 \\ \text { Part-year employees } & 947 & 27.96 & 8891 & 1011 \\ \text { of which mainly full-time } & 723 & 28.88 & 10411 & 1195 \\ \text { mainly part-time } & 224 & 24.97 & 3973 & 413\end{array}$

All employees

2892

1747

Women

Full-year employees

of which mainly full-time mainly part-time

Part-year employees

of which mainly full-time

mainly part-time

1228

42.49

51.93

11535

15202

51.94

17919

51.89

8780

1773

520

28.07

5937

2110

1145

29.03

8348

655

27.36

4134

977

726

1118

433

A11 employees

Full-year employees

of which mainly full-time mainly part-time

Part-year employees

of which mainly full-time

mainly part-time

6908

4816

4161

655

2092

1213

879

44.70
51.94
51.95
51.88
28.02
28.94
26.75

Persons

$\begin{array}{rr}16399 & 1686 \\ 20362 & 2048 \\ 22138 & 2220 \\ 9071 & 954 \\ 7274 & 855 \\ 9578 & 1164 \\ 4093 & 428\end{array}$

Notes:

a) Data relate to fiscal year 1985-1986 (July to June). Persons working for wages and salaries in their own limited liability company are included as employees. Among men, they earned 6.9 per cent of total wages and salaries of full-year full-time employees and 21.4 per cent of total wages and salaries of full-year part-time employees.

b) Weeks of employee work were estimated as a function of recorded data items as the maximum of total weeks worked less weeks worked as self-employed, total weeks worked as dependent employee, and total weeks worked for own limited liability company.

c) Hours are estimated from grouped data as the mid-point of the range and as 54 hours for workers in the class 50 hours and above.

d) Full-year employees are those who worked as employees 50-52 weeks. Persons classified as full-time workers by ABS but who had weekly hours in employee statuses less than 30 hours were re-classified as part-time.

Source: Australian Income Distribution Survey 1985-6, individual record data supplied to the Secretariat by Australian Bureau of Statistics, grossed up to a population basis using weights supplied in the data. 
Table B. 3.

Statistics of average annual earnings and hours on various definitions, Australia 1985-6

Definitional basis (a)

Number

Earnings

Hours

Men

1. All with any employment

2. Annual average employment

$4015 \quad 19903$

22355

3575

23138

3454

4. Full-time equivalent (hours-based)

5. Full-year employees

6. Full-year full-time employees

3426

3068

23329

23302

23905

Women

1. All with any employment

2. Annual average employment

3. Full-time equivalent (part-time $=1 / 2$ )

1931

4. Full-time equivalent (hours-based)

1878

5. Full-year employees

1747

6. Full-year full-time employees

1228

11535

1358

14118

1663

17273

2034

17764

2092

15202

1773

17919

2110

\section{Persons}

1. All with any employment

6908

16399

19077

1686

2. Annual average employment

5938

21035

1962

3. Full-time equivalent (part-time $=1 / 2$ )

5385

21358

2163

5. Full-time equivalent (hours-based)

5304

20362

2196

6. Ful1-year full-time employees

4161

22138

2048

2220

\section{Note:}

a) Definitional bases 1,5 and 6 relate to actual counts of persons, definitions 2-4 relate to weighted averages of persons. Earnings and hours statistics $1-4$ are based on total earnings and hours in the economy. while earnings and hours statistics 5 and 6 are based on earnings and hours of full-year and full-year full-time employees only.

Source: calculated from statistics in Table B. 2 . 


\section{Annex C \\ Definition and sources for information on full-year full-time earnings}

A possible specification of coverage of statistics for full-year full-time earnings, for employees, is:

Data for persons of all ages in all occupations and industries who were employees mainly full-time for the full year, including persons who changed employer. Full year employment status is based on employment durations including the periods of holiday, absenteeism, sickness, etc. which constitute employment in the sense of the ILO definition of employment. Owner-managers of incorporated businesses, whose earnings are wage and salary in the national accounting sense, are considered to be employees. Wages and salaries include bonuses, directors fees and employee social security contributions, but exclude social security contributions paid by employers. Earnings from second wage and salary jobs are included but earnings from secondary self-employment are excluded.

In practice, statistics shown in Table 5 are only approximations to this definition, depending upon what is published. Statistics from employer surveys will cover not cover second jobs: some further details are given below.

\section{Sources:}

Australia: see Annex B.

Canada: $\quad$ Earnings of Men and Women. 1986, Statistics Canada 13-217, Table 3 .

Denmark: Indkomster og Formuer 1983 og 1984 , Table $27 \mathrm{~B}$, and communication from Danmarks Statistik.

Finland: Income Distribution Statistics, Communication from the Central Statistical of Finland, based upon various issues.

France: Communication from INSEE based upon the DADS (Déclaration annuelles des données sociales) and SIASP (Système d'information sur les agents des services publics). These sources cover the private and semi-public sectors and central government employment (excluding overseas employment) respectively, and for 1986 the average earnings are made up as follows:

\begin{tabular}{lrrrr} 
& \multicolumn{2}{c}{ Employment } & \multicolumn{2}{c}{ Earnings } \\
& (thousand years) & (thousand francs) \\
Men & Women & Men & Women \\
Private and semi-public sectors & 7491 & 4091 & 99.634 & 73.974 \\
Central government & 988 & 869 & 107.911 & 92.325
\end{tabular}


Employment in local government, agriculture, and private domestic service (approximately 11 per cent of all full-time employment, as reported in Economie et Statistique, No.154) is not included. The original statistics refer to wages and salaries net of employee social security contributions and were converted to a basis gross of employee social security contributions using the contribution rates reported in Economie et Statistique nos. 141, 163, 178, 221.

Japan: Employment Status Survey, 1982 and 1987, Table 17. Earnings figures are Secretariat estimates of the average earnings based upon a distribution of employment by range of annual earnings.

Netherlands: Sociaal-economische maandstatistiek, January 1988, Table 2.2.3. Numbers surveyed are not reported here. Excludes workers in personal household service, embassies and international organizations, and military service workers doing social work; includes directors, apprentices and home workers. The average earnings tabulation used excludes workers aged 65 and over and those with monthly earnings over $12,750 \mathrm{gld}$. On the basis that such workers appear to represent about 0.2 per cent of employees and have average annual earnings of about 220,000 gld., the latter exclusion would reduce reported average earnings only by about 0.8 per cent.

Sweden: Inkomstfördelningsundersökningen 1986, Tables 16, 16A, 18, 19. Tables 16 and $16 \mathrm{~A}$ relate to 'income from work' and the ratio of wages and salaries to 'income from work' for the employees covered in Tables 18 and 19 ( 0.962 for men and 0.929 for women) was applied to these data.

UK: $\quad$ New Earnings Survey. Annual Earnings April 1978 to April 1979. Department of Employment 1980, Tables 1,10,11. Excludes Northern Ireland. For technical reasons exclude males aged under 21 and females aged under 18 whose pay was affected by an absence that resulted in loss of a full weeks' pay or more. Economy-wide employment totals were estimated using grossing up factors suggested for the 1987 New Earnings Survey, adjusted for changes in sample size and economy-wide total employment since 1979.

US: Communication from the Bureau of Labor Statistics of unpublished tables from the Current Population Survey. 